\title{
Making of a Good Teacher: Transformative Expressions of Inner Life in Education Narratives of Living, Being and Knowing Together
}

\author{
Gaurav Ojha* \\ School of Education, Kathmandu University, Lalitpur,Nepal
}

\begin{abstract}
This research paper recollects transformative expressions of inner life in education using expressive language to reconstruct experiential narratives of educators following on with collaborative turn as encouraged in qualitative research. Similarly, this paper reflects on transformative expressions of inner life in education by putting together first person monologues of educators, generated through dialogues. This paper, in addition, reveals their lived pedagogical experiences, their stories, hopes, courage, convictions, creativity and struggles in an education system where educators are most often encouraged to suppress their inner self, somewhere clandestine rather than share the relational richness of their inner life with students. Besides, the paper argues that good teaching takes its reference from inner landscape of an educator. My research participants are aware that by making a difference in their inner life and by infusing transformative orientations of their inner life within their educational practices, they can also make a difference in the lives of their students. They are able to sustain transformative interpersonal relationships with their students, which encourage them to live a life of selfawareness, freedom, character, joy, appreciation, acceptance and creativity. Finally, the paper ends with a realisation that inner life of an educator, including his/her compassion, courage, concern and care, serves as a guiding force for a meaningful relationship that creates transformative possibilities in education.
\end{abstract}

Keywords: Inner Life; Lived Pedagogical Practices; Dialogism in Qualitative Research; Transformative Orientations in Education

\section{Setting the Stage}

As an educator myself, teaching at different schools and colleges in Kathmandu, Nepal for about five years, now I am utterly convinced that the expressions of inner life in pedagogical practices of educators make a transformative impact on the lives of their students. And, this inner conviction of mine has germinated through various transformative encounters I shared with my students, romping in their thoughtless age varying from early 
to late teenage years. More importantly, hereby sharing her inner qualities an educator can help her students explore and discern the meaningfulness of their individual lives. However, I often find that most of my fellow educators are leaving behind the traces of their humane, holistic, creative and spiritual dispositions, hiding it somewhere or suppressing it inside the inner closets of their mind clandestine rather than sharing those transformative qualities of their inner life with their students or expressing it while engaging with their educational practices in diverse ways within different educational contexts. Sadly, we educators, including myself, are part of an education that considers human beings just as the $\operatorname{cog}$ in a big machine with any agency, sense of freedom or subjectivity.

We are living in a society, as Martin Luther King Jr. (2000) argued, that puts all its emphasis on judging success by the index of our salaries and the size of our automobiles rather than by the quality of our service and our relationship to humanity (as cited in Kates \& Harvey, 2010). Hence, for most of the conventionally shaped educators, the main focus behind our educational practices has always been to mindlessly follow an approach to education that favours and meets the requirements of a rigid system that tends to evaluate teaching and learning process merely in quantitative terms without any traces of humanistic, holistic and spiritual

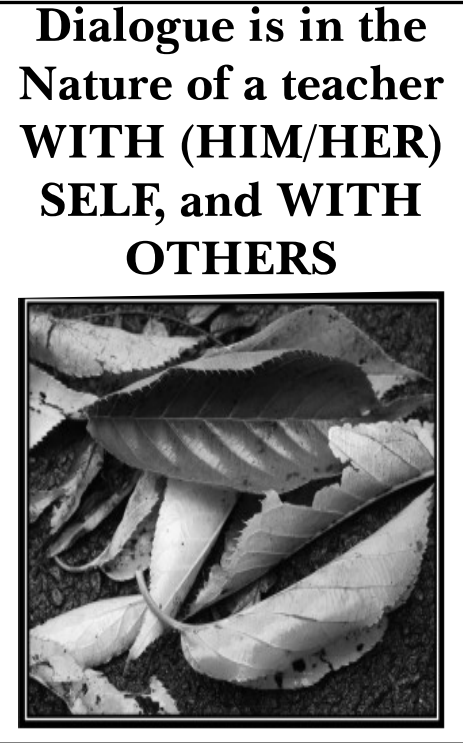
qualities within it.

In this narrow approach to education, as Miller (2009) argues, educators consider themselves as the dispenser of knowledge, authority of truth, and evaluator of learning. And, the academic achievement of the student is considered as his/her ability to display, repeat, or transmit the selected body of information back to an educator, examiner or to some other measuring authority. Sadly, for most of the educators I have had to engage with, they come to their schools and colleges, and also enter inside the classrooms and engage in their activities with this narrow and constrained view of education. For them, the notions of inner lives, transformative pedagogy, and holistic education belong to ancient past and that never really belong to this scientific, modern and competitive age. They feel that the concepts of soul, love, empathy,

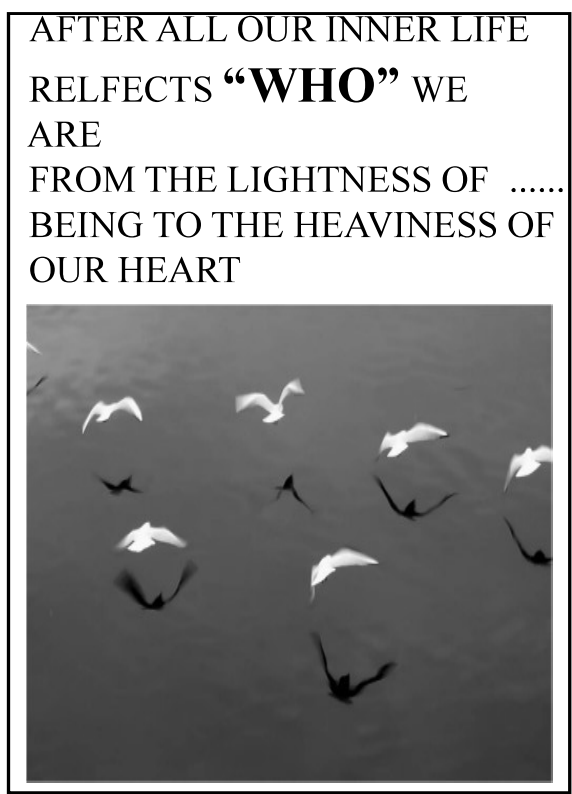


Making of a Good Teacher: Transformative Expressions 45

creativity, relationship and compassionnever really belong to modern progressive educational system. Moreover, as reflected in their educational practices they are satisfied and content with their conjecture of consumerist approach in education.

However, there are some educators who take their courage andreconceptualise education beyondmere process of just exchanging information, stuffing minds with standardised norms and practices and teaching students how to make an earning and living out of what they have been stuffed with. Furthermore, their orientation towards education is radically different. They regard education as a process of infusing holistic practices, spiritual experiences and creating spiritual transformation so that students learn to live a life of awareness, character, joy, appreciation, acceptance, celebration, connection, empathy and love.

Again, as Kates and Harvey (2010) argue, for some educators their teaching approach and learning activities involve more than a consumerist approach to education. Rather than just offering their student mere information on any particular topic, their approach overall involves the inner development of the learners. Hence, these educators argue that the art of education is to make the lives of their young students; soul-full, creative, inspirational and spiritual.

As modern approach of consumer education aims to assemble students for a life of earning, it utterly overlooks their inner life that yearns for awareness, of emotion, ethics, joy, energy, admiration, acceptance and more importantly love (Kates \& Harvey, 2010). Therefore, most of our students receive education that is far off from nourishing and nurturing their spirits. In any case, the scope of education has become so narrow and trivial that even educators who are aware of the urgent need for a holistic, transformative and spiritual dimension in education are hesitant to put forth its worth more than a market value at a certain selling price, attractive enough for people with certain purchasing power. No one takes courage to speak about values of education beyond the logic of the market. Therefore, as Palmer (2009) defines it, much of modern education has become soulless that modern schools and colleges along with their curriculum and pedagogical practices are just death- dealing precisely because "we have driven the sacred out of it" (p.19). All in all, education has become a mere process rather than a purposeful activity. Moreover, this dullness is always on an expansion with very few educators who are ready and eager to infuse the transformative dimensions of their inner life into their teaching and learning activities. Therefore, the need for transformative orientations in education has always been overlooked and silenced.

Fortunately, there are those few educators, who are ready to embrace diverse ways in their educational practices to satisfy the inner spiritual hunger of their students. They come with a firm conviction that when we guide students in a constructive way to express their spiritual longings and creativity, young students can find purpose in life; can do better in their school; strengthen ties in family and with friends; and approach their remaining life 
with vitality to learn continuously and with visions for better realities. Moreover, these educators are also able to recognise the spiritual problem that plagues our culture and see the urgent need for evoking holistic/spiritual/transformative dimensions in education so that our schools and colleges can respond to the spiritual void - the sense of inner emptiness, meaninglessness, and disconnection many students feel.

Hence, for these educators including myself, education is ultimately a transformative activity. We as educators, conscious of our inner lives, donot feel hesitant to bring our inner courage inside our classrooms. We share the transformative qualities of inner lives with our students as we have

FROM BEING WHAT YOU ARE

BECOME WHAT YOU WANT TO BE DON'T HIDE YOUR INNER DARKNESS

KNOW YOUR SELF, BE THY SOUL

MAKER OF YOUR LIFE CARRY ON AND CARING FOR YOUR INTERGITY personally glimpsed for themselves all the riches of the inner lives in the reflections of our inner spiritual dispositions search, meaning and experiences. Here, the main concern for an educator like myself is to make our students aware of their deeper connections, possibilities and capabilities of their inner life.

Again, as Miller (2006) argues, educators and teachers need to nurture their inner selves so that they can nurture and nourish the fragmented and broken soul of their students. $\mathrm{He}$ even urges educators to set aside some time to spiritualise their inner lives by engaging in various contemplative activities of self-reflections and mindful meditation that awaken them to the richness of inner selves because without these activities we cannot recognise the spiritual needs and hunger of our students. More importantly, we cannot really satisfy their spiritual hunger without our focus on holistic pedagogical practices.

As an educator, I have been always conscious of these facts, and have made a stern effort to practise contemplative self-reflective practices to enrich my own educational practices and help my students in their search for meaning as they yearn for a flourishing life. But, I must confess, at many times I have experienced crisis within myself, being utterly unable to help students to find meaning and purpose in their lives. Moreover, from my own educational experiences, I can reflect on the notion that without meaning in their lives, students' motivation to learn is imperilled. We find many students today who cannot focus, listen, or donot even have the will to learn. Helping these students find their own inner motivation is a challenge for educators, who are struggling and slugging it out within our wretched education system.

Personally, and through other acquaintances, I have encountered few educators who are interested in spiritual dimensions in education. They practice spiritual exercises regularly and do not shy away from bringing their spiritual intelligence and awareness to 
Making of a Good Teacher: Transformative Expressions 47

their educational institutes and more precisely inside their classrooms with various holistic pedagogical practices. This research paper is about them, their inner lives, struggles, their lived world and their lived experiences, expressed through my reflective writings. More importantly, it is also about all the traces of impressions they have made inside my memories, heart and mind.

\section{Expressions of Inner Life in Education}

When it comes to expressions of educator's inner lives in education, I always think the concept of the inner teacher used by Parker J. Palmer to focus on the call to teach from within is extremely relevant. Palmer (2009) states that "the teacher within is not the voice of conscience but of identity and integrity. It speaks not of what ought to be, but of what is real for us, of what is true" (p. 32). So, a strong sense of personal identity should infuse into the work of the educator. He further argues that good teachers possess a capacity for interconnectedness (Palmer, 1998). They are able to weave a complex web of connections among themselves, their subjects, and their students so that students can learn to weave a world for themselves.

Likewise, in his seminal work 'The Courage to Teach', Palmer (1998) dissects and grades educators into four categories based on the questions and essential concerns of the educators. According to Palmer (1998), the basic question most of the educators commonly ask to themselves

Where is the Door to your soul? The heart is a window BE ON THE HEART AND OPEN YOUR

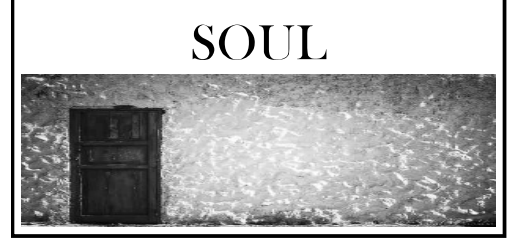
is -the 'what' question - what subjects shall we teach? And when educators go bit deeper in themselves, they ask the "how" question - what methods and techniques are required to teach well? Again only occasionally, when they go much deeper, they tend to ask the "why" question - for what purposes and to what ends do we teach? However, educators hardly ask the "who" question - who is the self that teaches? How does my selfhood synchronise or distort the way I relate to my students, my curriculum, my associates, and more importantly, my world?

Hence, for educators interested in inner dimensions know and ask themselves the fundamental question about the self that teaches how their inner being connects with their own profession; with their students and their subjects; and in what ways they can further nurture wholeness in them and in their students. Also, Palmer (2010) argues that the good teaching comes from the identity and integrity of an educator, meaning from the wholeness of a teacher. More importantly, his identity and integrity as an educator lies at the intersection of the diverse forces that make up who he is as a teacher. It also lies in how he relates to those forces in ways that bring him to wholeness rather than disintegration. 


\section{Enriching Inner Life in Education}

Sadly, most students in our schools and college system regardless of these positive connections never get taste of their inner lives. They spend most of their individual life with a delusion that inner and outer lives are separate, and that to be successful, spirit must be held at bay. Consequently, our students often suffer a sense of meaninglessness, arising from social and religious traditions that do not provide them with meaning, continuity, and connection (Kessler, 2000). Whereas, it is precisely a sense of meaning that the youth are searching for (Tacey, 2004). For educators with their holistic pedagogy and with certain inclination towards spirituality, they feel a spiritual hunger in their students. To this end, our educational institutions can become communities where students and teachers can experience their deeper connections together. In the search itself, in loving the questions, in the deep yearnings that students feel, educators believe their students would discover what is sacred in life, what is sacred in their own lives, and what allows them to bring their most sacred gifts to nourish the world (Kessler, 2004).

As educators "we teach who we are" (Palmer, 2010, p. 40). Hence, educators who invite their heart and soul into the classroom also find it essential to nurture their own spiritual development. Teachers develop personal practices that cultivate awareness, serenity and compassion, as well as collaborative efforts with other teachers to give and receive support for the challenges and joys of entering this terrain with their students (Kessler, 2000). Therefore, when teachers enrich their inner presence and open their hearts; they also learn to discipline their students with love. In doing so, they co-create climate of honour and respect with their students.

\section{Research Methodology}

For this research, I have settled with collaborative turn in qualitative research. As a collective whole, collaborative turn in qualitative research stands out to me as the generative nature of dialogism in a collaborative research process. According to Bakhtin (1935) dialogism is the multifaceted, layered social linguistic chain that is the starting place for all things including the self (as cited in Morson \& Emerson, 1990). Besides, my research participants are co-equal research partners and they constantly redefine and shape this collaborative research. This movement towards foregrounding the personal can be understood as a response to recognising the impossibility of separating one's self from the research one conducts; the necessity of more transparently acknowledging and locating one's biases; and a growing recognition of the importance of people's personal knowledge. Hence, in this research paper, I have collected the narratives, first person monologues and lived world stories of my participants, following collaborative turn in qualitative research. My research participants are capable of speaking for themselves their stories of livededucational experiences and express their narratives of self-transformations and inner lives with me in trust. Besides, I have observed pedagogical practices by observing their 
classroomactivities. Further, I also had dialogues with their students to get a comprehensive perspective about my research participants.

\section{Narrative of Living, Being, Teaching and Knowing Together}

Narrative-1: To Speak From Inner Self-As an educator, I wish for respectful relations with my students. I am open towards their experiences and understandings. I am also open towards them with utmost eager. I seek to empathize with them whenever they are around me. I want to share with them my presence. Together, I understand we are on a journey towards a realisation. My students help me realise myself with them. I want to improve myself collaboratively with my students. We are in this togetherness. As an educator, therefore, I want my students to understand that their achievement is not just limited to their academic subjects and test scores. I want them to realize through my inner presence that what matters most in life are respectful relationships- how you learn to relate with other human beings.

Narrative-2: To Speak From Inner Self-Sharing my own personal stories opens my students from within. I also let them see a glimpse of who I am, not only as a teacher but as a human being, who stands in front of the classroom. This is my way of relating with my students. I too have my struggles as a parent, husband, friend, community worker. I like to share my success and failure experiences to them. I also tell them about my fears and hopelessness. My story allows them to make sense of myself and enables them to understand inner struggles and difficulties of people all around them. With my stories, narrations and dialogues, I become more of a human to them, more real, authentic. It helps me relate deeply with each other. Similarly, I encourage them to share their stories and it's wonderful that after they hear my stories, they are so eager to tell their own stories. It encourages me to engage with them and their parents truthfully. When it comes to students, I won't allow them to make it too personnel. However, when I talk with them personally, I want them to open up and share themselves. This allows me to complement and understand children's learning at home. It makes me familiar to the role of their parents and it encourages me and them together to become involved in the classroom.

Narrative- 3 To Speak From Myself-Students matter to me. I want to take care of them with love and kindness. I want to put good thoughts in my students. I wish for them to take care for other people, plants, animals and the earth including all aspects of beings. I want them to make a big picture out of what they have learned. Many students in my classroom feel that they are deprived of love and I believe this is the root of violence,

\begin{tabular}{|c|}
\hline WE SEE \\
OURSELVES \\
AMONG SAND \\
AND PEBBLES \\
WE SEE ARE \\
SEEN \\
AND \\
THE WAY WE \\
SEE \\
US IN THEM \\
NOW AND \\
THEN \\
\hline
\end{tabular}


indifference, and carelessness of our students. All those behavioural problems, we find in our students, are because of the fact that we just don't care about them. More of caring environment in schools will eventually decrease these inconsistencies. As an educator, I always want to infuse empathy and care to be nurtured in all educational settings. All students irrespective of their performance or lack to it are respected as human being first.

Narrative-4 To Speak From Inner Self-As an educator, before I react or interact, I always try to put myself inside students'shoes. It is rather crucial for me as an educator to understand constantly that I need to be aware and conscious of individuality amongst my students. After teaching for years, now the most important thing I have learned from my educational experiences and from its reflections is that I need to learn to put myself in someone else's shoes.

I can't simply project or lash out my expectations and anticipations on them, and as an educator I feel that I need to be aware of my surroundings and understand how my students have different lived experiences, passions, and creativity. I must try to involve them in my educational practices. I encourage my students not to waste their time trying to become who they are not. Rather I encourage them to celebrate the present moments. We celebrate our differences. We celebrate our problems together.

\section{Reflections}

The most important aspect of teaching is the 'self' that teaches. My research participants make a claim that good teaching is an expression of identity and integrity of a teacher (Palmer, 1998). In other words, good teaching comes from good people. Here, the concepts of identity and integrity not only signify our noble features, but also the good deeds we do, or the brave faces we wear to conceal our confusions and complexities. Identity and integrity have as much to do with our shadows and limits, our wounds and fears, as with our strengths, struggles, courage and potentials combined together.

For Palmer (1998), a strong sense of personal identity infuses with the work of a teacher- with his/her teaching and learning practices. He argues that good teachers possess a capacity for connectedness; they are able to weave a complex web of connections among themselves, their subjects, and their students so that students can learn to weave the world for themselves. Further, Palmer (2009) says that good teachers bring students into living communion with the subjects they teach. They also bring students close to their community, with themselves for each other. Besides, the concern here is how schools can educate students if they fail to support the teacher's inner life. To educate is to guide students on an inner journey towards more truthful ways of seeing and being in the world. Hence, inner life of an educator is an integral part of educational practices because as educators we teach who we are. After all, as Palmer (1998) argues, teaching like any truly human activity emerges from one's inwardness, for better or worse and hence educators need to listen to the voice within, the voice that invites teachers to honour their true selves. 


\section{Making of a Good Teacher: Transformative Expressions 51}

For Palmer (2010), the goal of education is for each individual to develop his or her authentic self. This can best be accomplished in what Palmer calls a community of truth created by teachers who know their own hearts - individuals struggling with the question 'who' is the self that teaches. For Palmer (2010), community of truth is grounded in the claim that reality is a complex web of relationships, where we explore, know, struggle and enrich ourselves together. Therefore, from a transformative perspective, the dialogue between the teacher and the student is a critical aspect of education.

Speaking with me, as I reflect along, I realise that awareness of inner lives infuses a sense of integrity in teaching and learning activities. And my reflections speak to me that educatorswho donot understand theirown inner complexities, inner complexities of theirstudents, and how both these inner complexities intermingle in teaching and learning activities will find it difficult to understand the transformative reorientations in education.

Moreover, rather than being a passive recipient of information, my research participants regard their students as fully engaged human beings, together with their educator, moving towards new learning possibilities (Palmer, 2009).Thus, they challenge the traditional approaches to education and acknowledge that considering learners as passive recipient has led to a consideration of educational process as a transaction, without any appreciation for the educational context within which the teacher is with the students.

Similarly, Miller (2006) suggests that the transformative education process calls out for and impacts the inner soul of educators and students. As such, education has a transformative outcome that occurs in the relatedness of those engaged in the education practices. Palmer (2009) also uses the term spiritual to describe the diverse ways we answer the heart's yearning to be connected relationally. There is a link that exists between the sacred, the spiritual, and with our awareness an innate relational connectedness with other human beings. Hence, after reflecting on the narratives of my research participants, I also get a sense that importance of human relationships cannot be overlooked in educational practices especially when it serves as a guiding force for meaningful relationship that enriches and sustains transformative possibilities in education.

More importantly, within the framework of transformative perspective, education particularly focuses on strengthening human relationships; how one relates to oneself, to other human beings, to the social world, to the natural environment, and to existence as a whole. Hence, enriching spirituality as an expression of inner life in education strengthens human interconnectedness shared between educators and their learners in teaching, learning and understanding. Again, while reflecting on transformative educational practices of my research participants, I realise that orienting spirituality in education means we allow time for students and teachers to listen and express their inner life, to enjoy silence, to find spaces for creativity and compassion, and to engage with the natural world, gently and sympathetically. Besides, as we recognise inner life of educators and students, we also value them as unique individuals, who can reorient their educational practices as 
52 G. Ojha

transformative, and this realisation also enables individuals involved in education to accept and embrace multiple layers of relationships working all around us. Moreover, this relational dynamics of transformative teaching and learning contextualises itself within the framework of expressions of inner life and its spirituality.

\section{Closing Remarks}

From the transformative perspective, the essence of good teaching is the capacity to connect and only those educators who acknowledge their inner life, maintain a transformative relationship they share with their students. Those who are capable of sustaining humanistic values in their students have the gift of being good teachers. A transformative pedagogical and relational orientation of educators is an expression of being true to who you are. Here, it is important to comprehend that all my research participants infuse transformative expressions of their inner life into their teaching and learning activities. They find that their outer and inner lives areclosely attuned. Moreover, their inner freedom, harmony and creativity allow them to unleash freedom, harmony and creativity in their classroom practices. Therefore, their educational practices reflect a transformative way of being, doing and living together in education, where seeking transaction of knowledge is not enough, since the ultimate purpose of education is to transform individuals by giving them a sense of meaning and a purpose in their life and to help them become a caring, creative, critical, more conscious and meaningful human being. After all, an educator who is aware of her inner life knows that by making a difference in her inner life, she can also make a difference in the lives of her students.

\section{References}

Kates, I. C., \& Harvey, C. L. (Eds.). (2010). The wheels of soul in education: An inspiring international dynamic. Rotterdam, The Netherlands: Sense.

Kessler, R. (2000). The soul of education: Helping students find connection, compassion, and character at school. Virginia: ASCD.

Kessler, R. (2004). Nourishing adolescent spirituality. In J. Miller, S. Karsten, D. Denton, D. Orr, \& I. C. Kates (Eds.), Holistic learning and spirituality in education: Breaking new ground (pp. 101-107). New York, NY: State University of New York Press.

Palmer, P. J. (1998). Evoking the spirit in public education. Educational Leadership, 56, 611.

Palmer, P. J. (2009). A hidden wholeness: The journey toward an undivided life. New Jersey, NJ: John Wiley \& Sons.

Palmer, P. J. (2010). The courage to teach: Exploring the inner landscape of a teacher's life. New Jersey, NJ: John Wiley \& Sons.

Journal of Education and Research, August 2017, Vol. 7, No. 2 
Making of a Good Teacher: Transformative Expressions $\mid 53$

Miller, R. (2006). Reflecting on spirituality in education. Encounter: Education for Meaning and Social Justice, 19(2), 6-9.

Miller, R. (2009). Caring for new life: Essays on holistic education. Brandon, VT: Foundation of Educational Renewal.

Morson, G. S., \& Emerson, C. (1990). Mikhail Bakhtin: Creation of a prosaic. Palo Alto, CA: Stanford University Press.

Tacey, D. (2004). The spirituality revolution: The emergence of contemporary spirituality. Abingdon, England: Routledge. 